Primljen / Received: 10.2.2013. Ispravljen / Corrected: 23.5.2013.

Prihvaćen / Accepted: 29.5.2013.

Dostupno online / Available online: 25.7.2013.

\section{Influence of natural fillers on shear strength of cement treated peat}

Authors:

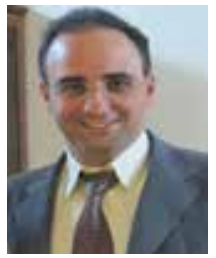

Ali Dehghanbanadaki, B.Sc.CE Universiti Teknologi Malaysia Faculty of Civil Engineering A.dehghan1916@yahoo.com

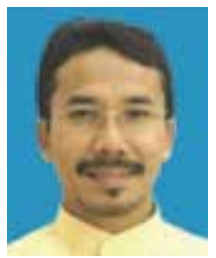

Assoc. Prof. Kamarudin Ahmad, PhD. CE Universiti Teknologi Malaysia

Faculty of Civil Engineering

kamarudin@utm.my

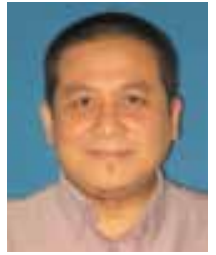

Nazri Ali, PhD. CE

Universiti Teknologi Malaysia

Faculty of Civil Engineering

nazriali@utm.my

\section{Ali Dehghanbanadaki, Kamarudin Ahmad, Nazri Ali}

\section{Influence of natural fillers on shear strength of cement treated peat}

A study on peat soil stabilization by using cement and different natural fillers is presented in the paper. In the scope of this study, natural fillers are mixed at various dosages with cement treated peat in order to evaluate the unconfined compressive strength. The results indicate that the mix design of $300 \mathrm{~kg} / \mathrm{m}^{3}$ cement, with $125 \mathrm{~kg} / \mathrm{m}^{3}$ of well graded sand by mass of wet peat, gives the highest uniaxial compressive strength at 90 days of curing. Other fillers decrease the strength of stabilized peat.

\section{Key words:}

fibrous peat, stabilization, natural fillers, uniaxial compressive strength

Stručni rad

\section{Ali Dehghanbanadaki, Kamarudin Ahmad, Nazri Ali}

\section{Utjecaj prirodnih punila na posmičnu čvrstoću treseta ojačanog cementom}

U radu su prikazana istraživanja stabilizacije tresetnog tla cementom i različitim prirodnim punilima. U svrhu istraživanja, prirodna punila u različitim su omjerima pomiješana s tresetom ojačanim cementom te su izmjerene tlačne čvrstoće. Rezultati upućuju na to da mješavina s $300 \mathrm{~kg} / \mathrm{m}^{3}$ cementa i $125 \mathrm{~kg} / \mathrm{m}^{3}$ dobro granuliranog pijeska u odnosu na masu vlažnog treseta ima najveću jednoosnu tlačnu čvrstoću nakon njege od 90 dana. Ostala su punila smanjila čvrstoću stabiliziranog treseta.

Ključne riječi:

vlaknasti treset, stabilizacija, prirodna punila, jednoosna tlačna čvrstoća

Fachbericht

Ali Dehghanbanadaki, Kamarudin Ahmad, Nazri Ali

\section{Einfluss natürlicher Füllmittel auf die Scherfestigkeit von durch Zement verstärktem Torf}

Die vorliegende Arbeit beschreibt Untersuchungen zur Stabilisierung von Torfböden mit Zement und anderen natürlichen Füllmitteln. Mit dem Ziel der gegebenen Erforschungen sind natürliche Füllmittel verschiedener Dosierungen mit durch Zement verstärktem Torf gemischt und die entsprechenden Druckfestigkeiten ermittelt worden. Die Resultate weisen darauf hin, dass eine Mischung von $300 \mathrm{~kg} / \mathrm{m}^{3}$ Zement und $125 \mathrm{~kg} / \mathrm{m}^{3}$ gut granuliertem Sand im Vergleich zur Masse des feuchten Torfs nach einer Betonhärtung von 90 Tagen die größte nicht einachsige Druckfestigkeit besitzt. Andere Füllmittel haben die Festigkeit des stabilisierten Torfs vermindert 


\section{Introduction}

Peat soils are considered to be an extremely soft, wet and unconsolidated deposit. Low bearing capacity, very high compressibility, and difficult accessibility, demonstrate problematic properties of the peat [1]. These soils have been classified into 10 groups $\left(\mathrm{H}_{1}-\mathrm{H}_{10}\right)$ by von Post based on water content, fibre properties, and degree of decomposition [2]. In the US, the peat is found in 42 states with the total area of 30 million hectares [3]. These soils accumulate if the rate of decay is slower than the addition [4]. The complexity of chemical and physical properties of the peat with stabilizer materials is such that it is not possible to predict for a given site which stabilizer and dosage will yield optimum performance [5]. Besides the difference in water content, the peat also differs notably in its organic content which leads to different reactions with stabilizers [6]. Fibrous peat is mostly made of the weakly decomposed plant remains which are not destroyed by rubbing. It is extremely acidic and has a high fibre content. The range of acidity in peat is very wide and so the $\mathrm{pH}$ value of most peats varies from 2 to 6 [7]. The in situ void ratio of fibrous peat is very high due to hollow cellular fibres and high initial water content [8]. According to Kogure et al [9], peat contains the inner and outer void spaces that cause higher settlements compared to other soils. The void ratio as high as 25 can be found in fibrous peat whilst the void ratio as low as 9 is possible for a denser amorphous peat [10]. Mesri et al. [11], define these superficial deposits as soil with a very high in situ water content of $500 \%$ to $2000 \%$, which corresponds to the in situ void ratio ranging from 7.5 to 30 , respectively. Natural fillers play a vital role in enhancing the bond in the cementation reaction of soil mixing. Actually there is no chemical reaction between products of cement hydration and sand particles, but it increases the soil strength by decreasing the void ratio of the cement treated peat [12]. So these high void ratios can lower the bearing capacity, which is why the peat is considered as an unsuitable soil for foundations in its natural state.

Different ground improvement methods have been used to increase the bearing capacity of peat but, in comparison, deep soil mixing has proven to be more economical and needs minimum time [13]. This ground modification technique has been used for many diverse applications including building and embankment foundations, retaining structures, liquefaction mitigation, temporary support of excavations, and water control. In this method, hydraulic mineral binders are mixed with in situ peat to form a columnar reinforcement in the deep peat ground. Since peat has a high water content, it can provide water that is required for binder reactions. Therefore the dry mixing method is more effective for peat soil improvement compared to the wet mixing method [14]. Although a variety of laboratory and field studies have shown that cement is very effective in improving the bearing capacity of fibrous peat $[5-6,15]$, the failure of these columns is often attributed to unsuitable type and insufficient dosage of binder that is added to the soil [12]. Thus, there is a need to ameliorate the strength properties of stabilized peat columns. The shear strength of peat can generally be determined by in situ methods such as the field vane shear test and cone penetration test. Due to the fibrous structure of peat, its shear strength is somewhat different from that of mineral soil. The peat is mostly considered as a frictional material due to high fibre content [16]. But this high friction angle will not demonstrate high shear strength because the fibres are filled with water and gas. In laboratory, the most common test for determining the undrained shear strength $\left(\mathrm{s}_{\mathrm{u}}\right)$ is the uniaxial compression strength (UCS) test. The undrained shear strength of a cohesive soil is equal to one-half of the uniaxial compressive strength $\left(q_{u}\right)$. This test has been found to be an effective and economical method to determine the binder content that is required to obtain a specific shear strength. It is obvious that high organic content of peat can impede the stabilization process and normally peat needs greater quantities of binder than do inorganic soils. Thus, in order to neutralize this effect, the quantity of binder needs to exceed the threshold as shown in Figure 1 [5].

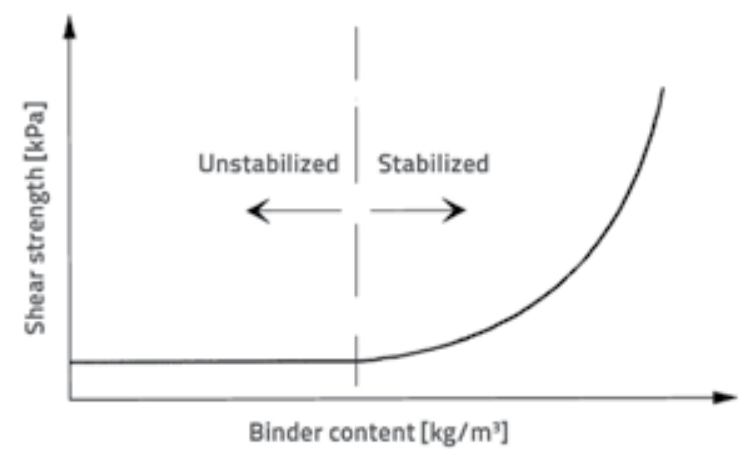

Figure 1. General Relationship between binder dosage and shear strength in peat soils, EuroSoilStab [5]

Several researchers have conducted laboratory experiments to study the effect of binders on the shear strength of peat soils. According to Wong et al [17] the uniaxial compressive strength of stabilized peat increases to $142.5 \mathrm{kPa}$ at the minimum dosage of $250 \mathrm{~kg} / \mathrm{m}^{3}$ for $75 \%$ cement and $25 \%$ slag, and to $178.6 \mathrm{kPa}$ using $300 \mathrm{~kg} / \mathrm{m}^{3}$. This quantity of binder is confirmed by Axellson [6] who observed that the dosage of $400 \mathrm{~kg} / \mathrm{m}^{3}$ presents lower strength than $250 \mathrm{~kg} / \mathrm{m}^{3}$, which shows that the water binder ratio has a significant effect on the shear strength of stabilized peat. Hebib and Farrell [15] stabilized fibrous peat and declared that the minimum dosage for peat soil activation is $150 \mathrm{~kg} /$ $\mathrm{m}^{3}$. According to Chen and Wang [18], the peat strength of 300 $\mathrm{kPa}$ could not be reached at the cement ratio of up to $30 \%$ with the deep mixing method at a foundation reinforcing project on peat. In general terms, parameters that affect significantly the shear strength of cement stabilized soil are the water content, liquid limit, sand and fines content, density, the amount of added cement, curing time, and pH value [19]. Therefore, choosing an appropriate quantity of binder is of decisive significance for the improvement of peat soils.

Engineering properties of fibrous peat originating from southern Malaysia are studied in this paper. In addition, series of uniaxial 
compressive strength tests have been carried out in order to evaluate the effect of various natural fillers on the uniaxial compressive strength (UCS) of the cement treated fibrous peat (hereinafter called cement peat) at different curing times. In fact, the study focuses on finding an optimum dosage of natural fillers at which the highest shear strength can be achieved.

\section{Laboratory experiments}

\subsection{Materials}

Disturbed and undisturbed peat samples were collected at Pontian, in the state of Johore, Malaysia, at the depth of about $1 \mathrm{~m}$. Soft peat is frequently encountered in this area. In order to evaluate the undrained shear strength of the soil, vane shear tests were performed at different locations. This peat is famous for its low undrained shear strength and compression modulus [20]. The laboratory testing programs comprised basic tests on undisturbed peat specimens, and uniaxial compression tests on stabilized specimens. An ordinary Portland cement (hereinafter called cement) was used in the study as the binding agent. As shown in Figure 2, four types of natural fillers containing well graded sand $(S W)$, poorly graded gravel (GP), coarse poorly graded sand (C-SP), and fine poorly graded sand $(\mathrm{F}-\mathrm{SP})$, were used in this study.

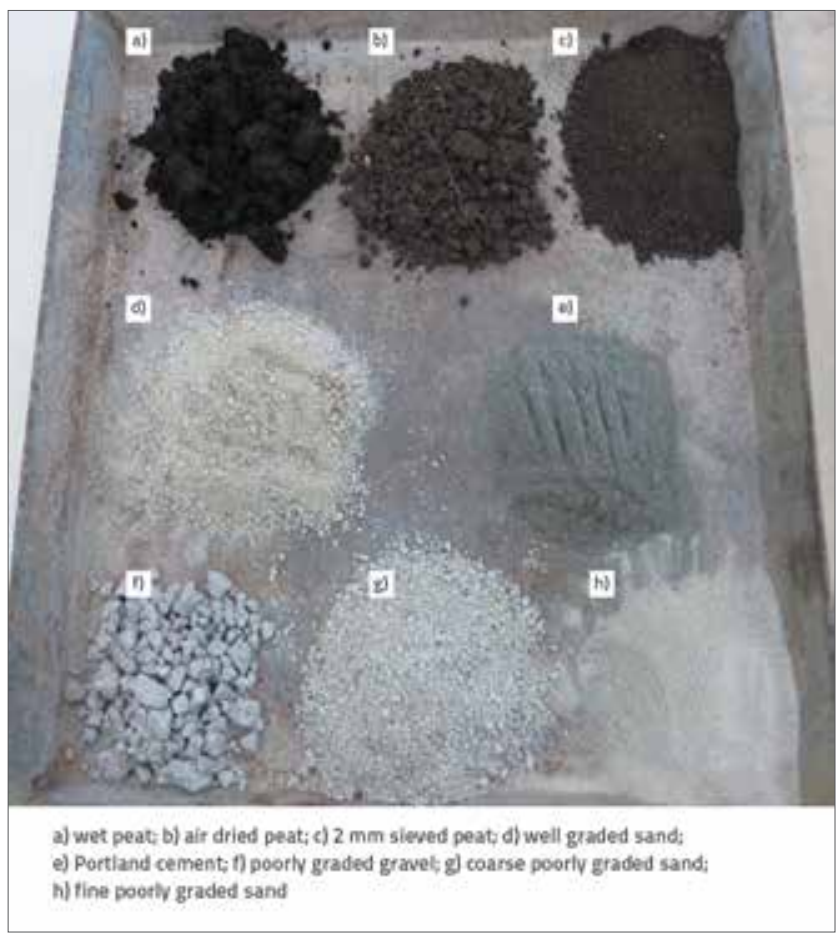

Figure 2. Different materials used in this study

\subsection{Preparation of samples}

In this study, samples were prepared based on the EuroSoilStab design guide [5]. According to this design guide, the binder quantity is expressed in $\mathrm{kg} / \mathrm{m}^{3}$ relative to the wet mass of the peat. For instance, if we take that the density of peat is 1000 $\mathrm{kg} / \mathrm{m}^{3}$ and if the prescribed cement quantity is $300 \mathrm{~kg} / \mathrm{m}^{3}$, then $300 \mathrm{gr}$ of cement are needed for each $1000 \mathrm{gr}$ of wet peat. After this, the quantities of natural fillers are calculated based on weight of the wet cemented peat. It should be noted that all stabilized peat samples used in this study were at their original natural moisture content of about $495 \%$ ( $\pm 5 \%$ ). Therefore, no water was added to the natural peat soil during mixing with cement and different natural fillers. For the curing process, the stabilized peat specimens were kept in the closed and covered PVC moulds and maintained during the curing time at the temperature of $25^{\circ} \mathrm{C}$.

The air-dried peat was first passed through a $2 \mathrm{~mm}$ sieve in order to remove coarse materials such as roots and large fibres. Water was added to achieve the natural water content of the peat, which was $495 \%$. A kitchen mixer was used to mix and homogenize the wet peat. Then the peat was mixed with cement and natural fillers for 10 minutes before it was placed in PVC moulds $38 \mathrm{~mm}$ in internal diameter and $250 \mathrm{~mm}$ in height. The prepared specimens were cured for 14,28 and 90 days. The quantity of cement for each specimen was $300 \mathrm{~kg} / \mathrm{m}^{3}$ relative to the weight of wet peat at its natural water content. Natural fillers were added to the cement peat at binder dosages of 50 , $75,100,125,150,175$ and $200 \mathrm{~kg} / \mathrm{m}^{3}$, relative to weight of the wet cemented peat. After curing, the specimens were extruded from PVC moulds and trimmed down to the height of $76 \mathrm{~mm}$ for testing. The total of 98 specimens containing undisturbed and stabilized peat with a different mix design were prepared and cured before testing. Various compositions of natural fillers used in testing are depicted in Table 1.

Table 1. Tests schedule

\begin{tabular}{|c|l|}
\hline $\begin{array}{c}\text { Number } \\
\text { of tests }\end{array}$ & Composition of soil specimen \\
\hline 11 & Undisturbed peat \\
\hline 3 & $100 \%$ OPC \\
\hline 21 & $\begin{array}{l}100 \% \text { OPC }+\left(50,75,100,125,150,175,200 \mathrm{~kg} / \mathrm{m}^{3}\right) \\
\text { Filler } 1(\mathrm{SW})\end{array}$ \\
\hline 21 & $\begin{array}{l}100 \% \text { OPC }+\left(50,75,100,125,150,175,200 \mathrm{~kg} / \mathrm{m}^{3}\right) \\
\text { Filler } 2 \text { (GP) }\end{array}$ \\
\hline 21 & $\begin{array}{l}100 \% \text { OPC }+\left(50,75,100,125,150,175,200 \mathrm{~kg} / \mathrm{m}^{3}\right) \\
\text { Filler } 3(\text { Coarse SP) }\end{array}$ \\
\hline 21 & $\begin{array}{l}100 \% \text { OPC }+\left(50,75,100,125,150,175,200 \mathrm{~kg} / \mathrm{m}^{3}\right) \\
\text { Filler } 4 \text { (Fine SP) }\end{array}$ \\
\hline Note: OPC - Ordinary Portland cement \\
\hline
\end{tabular}

\subsection{Methods of testing}

In order to evaluate the undrained shear strength of stabilized peat specimens, various uniaxial compression tests were conducted in accordance with BS 1377:1990: Part 7: section 7[21]. Specimens used in this study measured $38 \mathrm{~mm}$ in diameter and $76 \mathrm{~mm}$ in height. The 
axial load was applied vertically at the constant rate of $1.42 \mathrm{~mm}$. min ${ }^{1}$,as shown in Figure. 3. Care was taken to ensure that both ends of the specimen are flat to minimize bedding error, especially in case of stiffer samples. The test was considered complete either when a definite peak was obvious, or when the $20 \%$ strain was reached, whichever occurred first. Three main types of failure occurred during the testing: plastic failure in which the specimen bulges laterally into a barrel shape, brittle failure in which the specimen shears along one or more surfaces, and an intermediate failure [22].

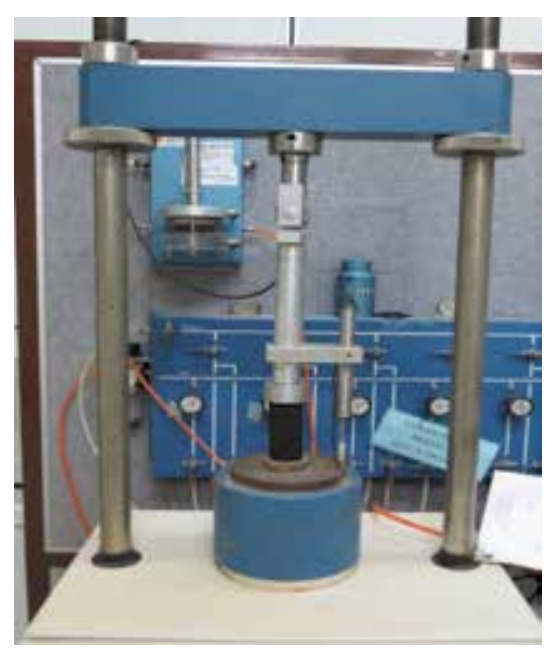

Figure 3. Uniaxial compression test using $5 \mathrm{kN}$ load frame

\section{Results and discussions}

\subsection{Basic results}

It was established by close examination that the ground water table is at $0.5 \mathrm{~m}$ below the ground level, which shows that the peat has a high water holding capacity. It was observed that the peat is somewhat pasty and that the muddy water can be squeezed out. The plant structure can easily be identified. It has a highly fibrous fabric and individual fibers $1-5 \mathrm{~cm}$ long can easily be identified. Based on its level of humification, the soil can be classified as $\mathrm{H}_{3}$ according to the von Post classification system [2]. The grain size analysis of the peat and different natural fillers was carried according to BS 1377:1990: Part 2 [21]. The corresponding curves are shown in Figure 4. The physicochemical properties of peat samples and various properties of natural fillers were determined in laboratory based on the BS and ASTM standards [21, 23], as shown in Tables 2 and 3, respectively. The chemical composition of the cement, based on the manufacturer's information, is summarized in Table 4.

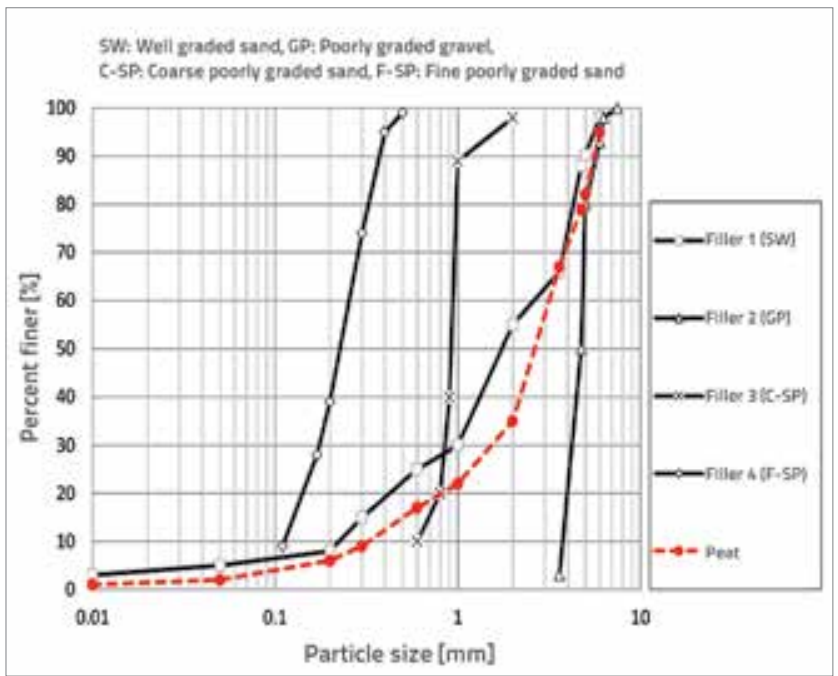

Figure 4. Particle size distribution curve of fibrous peat and fillers

Table 2. Properties of peat soil used in this study

\begin{tabular}{|l|c|c|}
\hline Parameter & Range & Average value \\
\hline Moisture content (BS 1377, 1990., Part 2) & $350-550 \%$ & $495 \%$ \\
\hline Bulk density (in situ) & $0,9-1,09 \mathrm{Mg} / \mathrm{m}^{3}$ & Fibrous \\
\hline Classification (ASTM 5715-00) & - & $\mathrm{H}_{3}$ \\
\hline Classification (von Post) & - & 1,38 \\
\hline Specific gravity (BS 1377, 1990., Part 6) & $1,29-1,42$ & $91 \%$ \\
\hline Organic content (BS 1377, 1990., Part 3) & $80-95 \%$ & $0 \%$ \\
\hline Fiber content (ASTM, 1997.-91) & $77-84 \%$ & $1,4 \mathrm{e}^{-5}(\mathrm{~m} / \mathrm{s})$ \\
\hline Permeability (BS 1377, 1990., Part 6) & - & 11 \\
\hline Void ratio (BS 1377, 1990., Part 4) & $9-12,5$ & $11 \mathrm{kPa}$ \\
\hline $\begin{array}{l}\text { Undrained shear strength-vane shear test } \\
\text { (BS 1377, 1990., Part 9) }\end{array}$ & $7-13 \mathrm{kPa}$ & $10 \mathrm{kPa}$ \\
\hline $\begin{array}{l}\text { Undrained shear strength-uniaxial compressive strength test } \\
\text { (BS 1377, 1990., Part 7) }\end{array}$ & $8-13 \mathrm{kPa}$ & \\
\hline
\end{tabular}


Table 3. Properties of natural fillers used in this study

\begin{tabular}{|c|c|c|c|c|}
\hline Parameters & $\begin{array}{c}\text { Filler } 1 \\
\text { SW }\end{array}$ & $\begin{array}{c}\text { Filler } 2 \\
\text { GP }\end{array}$ & $\begin{array}{c}\text { Filler } 3 \\
\text { C-SP }\end{array}$ & $\begin{array}{c}\text { Filler } 4 \\
\text { F-SP }\end{array}$ \\
\hline$C_{u}$ (Uniformity coefficient) & 12,5 & 1,38 & 1,5 & 1,9 \\
\hline$C_{c}$ (Coefficient of curvature) & 2 & 0,67 & 1,18 & 0,95 \\
\hline $\mathrm{e}_{\min }$ (Minimum void ratio) & 0,32 & N.A & 0,54 & 0,41 \\
\hline $\mathrm{e}_{\max }$ (Maximum void ratio) & 0,58 & N.A & 0,86 & 0,69 \\
\hline $\mathrm{G}_{\mathrm{S}}$ (Specific gravity) & 2,64 & 2,72 & 2,68 & 2,7 \\
\hline$\gamma_{\mathrm{d}(\max )}$ (Maximum dry density) & 17,51 & N.A & 16,9 & 16,87 \\
\hline$\Phi$ (Angle of internal friction) & 36,8 & N.A & 31,6 & 34 \\
\hline
\end{tabular}

Table 4. Chemical compositions of cement used in this study

\begin{tabular}{|c|c|}
\hline Constituent & $\%$ \\
\hline $\mathrm{SiO}_{2}$ & 21 \\
\hline $\mathrm{Al}_{2} \mathrm{O}_{3}$ & 5,3 \\
\hline $\mathrm{Fe}_{2} \mathrm{O}_{3}$ & 3,3 \\
\hline $\mathrm{CaO}_{2}$ & 65,6 \\
\hline $\mathrm{MgO}$ & 1,1 \\
\hline $\mathrm{SO}_{3}$ & 2,7 \\
\hline $\mathrm{Na}_{2} \mathrm{O}$ & 1 \\
\hline
\end{tabular}

\subsection{Uniaxial compression strength results}

When adding cement to soft soils, a certain decrease in water content and increase in density may be expected. This is due to the fact that the cement hydration reduces the water content of the stabilized peat, and produces solid products of cementitious material reactions [7]. If the cement quantity of $300 \mathrm{~kg} / \mathrm{m}^{3}$ is added to the wet peat specimens after 14 days of curing, the density increased from $1 \mathrm{Mg} / \mathrm{m}^{3}$ for undisturbed peat to the maximum density of about $1.37 \mathrm{Mg} / \mathrm{m}^{3}$. The density of all specimens remained approximately constant after 90 days of curing. Furthermore, the moisture content of cement peat was $125 \%$ after 14 days of curing, and it showed a very small reduction even after 90 days. It should be noted that the moisture content of all specimens mixed with different fillers showed a very small reduction (maximum $3 \%$ ), compared to 14 days curing. The highest uniaxial compressive strength (UCS) of 115.2, 163.7 and $170.93 \mathrm{kPa}$ was reached in stabilized peat specimens with cement only at a binder dosage of $300 \mathrm{~kg} / \mathrm{m}^{3}$ at 14,28 and 90 days of curing, respectively. As a comparison, the UCS values obtained in this study were almost the same as those of the stabilized peat, which was found to be 178.6 $\mathrm{kPa}$ using the binder dosage of $300 \mathrm{~kg} / \mathrm{m}^{3}$ with $75 \%$ cement and $25 \%$ slag, according to Wong et al [17]. Similar findings were made by Hebib and Farrell [15] who increased the UCS of untreated Raheenmore peat to about $180 \mathrm{kPa}$ using the binder dosage of $250 \mathrm{~kg} / \mathrm{m}^{3}$ with $60 \%$ cement, $40 \%$ pulverized fuel ash, and $3 \%$ lime, where the stabilized specimens were cured in water for 28 days. They have also established that the binder dosage of $250 \mathrm{~kg} / \mathrm{m}^{3}$ cement can increase the UCS of untreated peat up to $1100 \mathrm{kPa}$, which is significantly higher compared to this study. It clearly indicates that UCS of stabilized peat is very much site dependent.

Figure 5 shows a typical relationship between the UCS and axial strength of cement peat at the constant cement dosage of $300 \mathrm{~kg} / \mathrm{m}^{3}$ by mass of wet peat mixed with well graded sand at the dosage of $125 \mathrm{~kg} / \mathrm{m}^{3}$ by mass of wet peat, during 90 days of curing. The UCS of undisturbed peat was found to be $20 \mathrm{kPa}$, which is equal to the average shear strength of $11 \mathrm{kPa}$ achieved in situ using the vane shear test. As can be noticed, the highest UCS of $188.8 \mathrm{kPa}$ was attributed to SW followed by F-SP and C-SP with the UCS of 177.8 and $126.1 \mathrm{kPa}$, respectively.

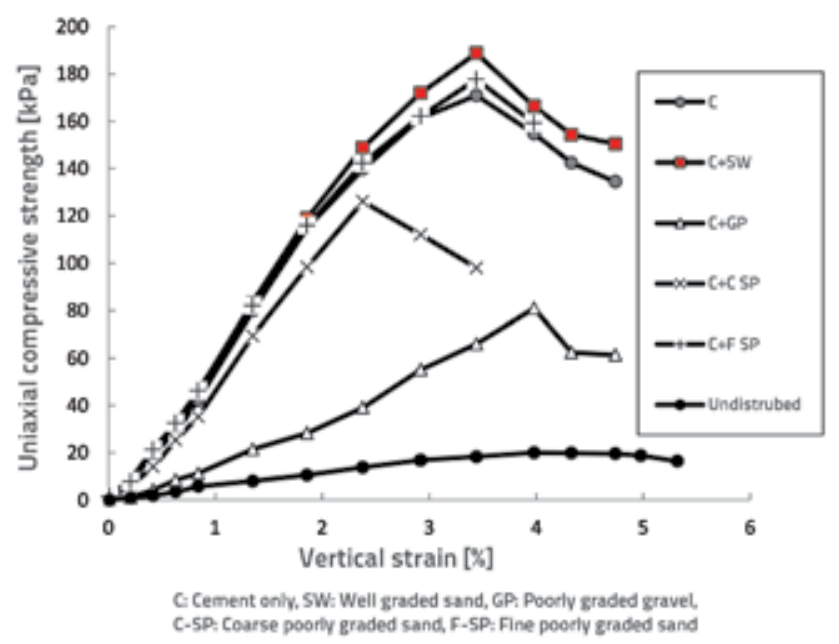

Figure 5. Relationship between uniaxial compressive stress and vertical strain of stabilized fibrous peat specimens 

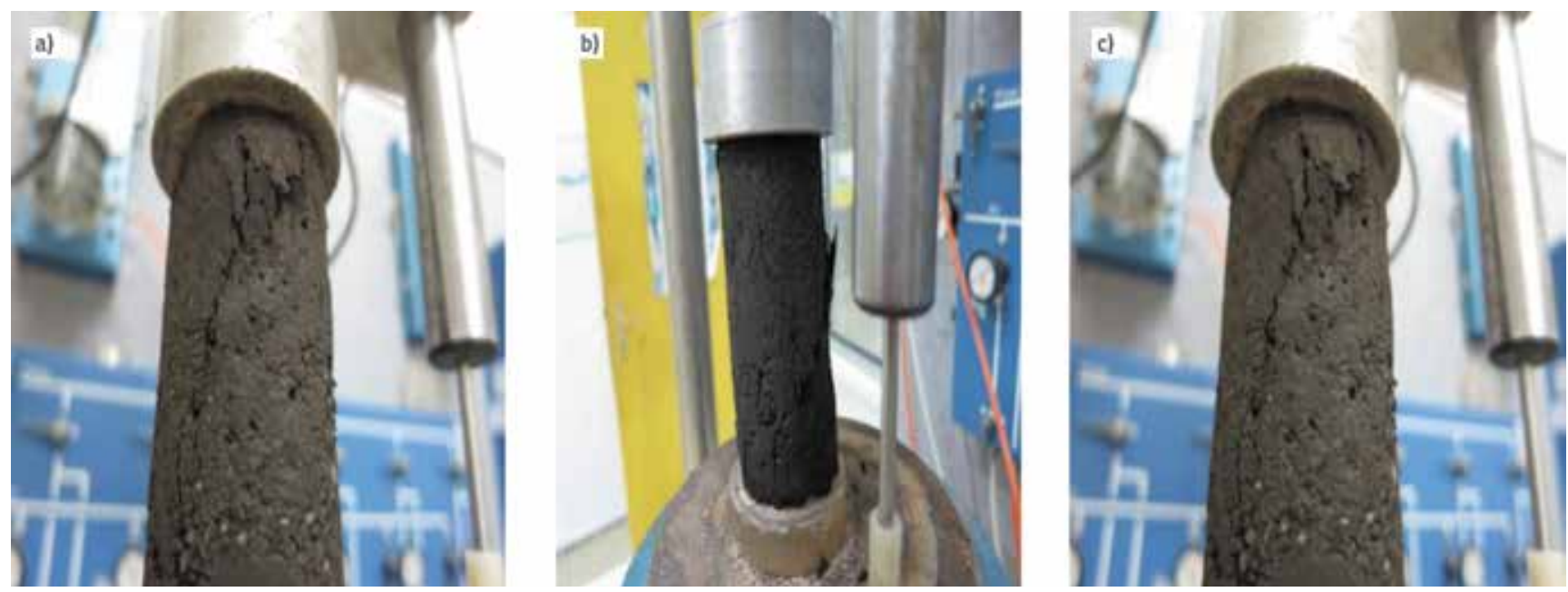

Figure 6. Modes of failure: a) cement peat (inclined crack); b) cement peat mixed with well graded sand (inclined crack); c) cement peat mixed with fine poorly graded sand (vertical crack)

It can be seen from Figure 5 that the inclusion of SW and F-SP increases the shear strength of cement peat and yields significantly higher UCS when compared to those mixed with GP and C-SP. This was attributed to the inclusion of different size of solid particles, which filled voids of the cement stabilized fibrous peat. Figure 5 also shows that coarse fillers decrease the shear strength of cement peat for up to $65 \%$. Similar trends can be observed for specimens mixed with different filler dosages at 14,28 and 90 days of curing. Different failure modes of stabilized peat are presented in Figure 6. Most of the specimens exhibit brittle failure while the undisturbed peat fails in a budging manner. Most cracks appear at an early stage at the top part of the specimen and propagate by stress increments until failure. As can be seen, specimens stabilized with cement fail by inclined crack only. The same trend was observed in the cement peat mixed with $\mathrm{SW}$, whereas vertical cracks appeared in most cement peat specimens mixed with F-SP. It should be mentioned that all stabilized specimens experienced small axial strain at failure which can be related to the brittle behavior of the specimens [17].

\subsection{Filler effect}

The influence of different natural fillers on cement stabilized peat has been analyzed. The results in terms of improvement ratio of the undrained shear strength of cement peat mixed with different dosages of natural fillers to the undisturbed peat, at three different curing times of 14, 28 and 90 days, are presented in Figure. 7. This Figure contains 7 groups of bar charts arranged according to the increase in filler content from $50 \mathrm{~kg} / \mathrm{m}^{3}$ in Figure $7 \mathrm{a}$ to $200 \mathrm{~kg} / \mathrm{m}^{3}$ in Figure $7 \mathrm{~g}$. It is obvious that the undrained shear strength of the cement stabilized peat increases with curing time. The data clearly show that improvement ratios increase significantly from 14 to 28 days of curing. On the contrary, improvement ratios increase only slightly from 28 to 90 days of curing. In these tests, the maximum improvement ratio of 9.44 was attributed to cement peat mixed with $125 \mathrm{~kg} / \mathrm{m}^{3} \mathrm{SW}$ at 90 days of curing (Figure $7 \mathrm{~d}$ ), while the improvement ratio levelled out at the minimum improvement of 1.65 for cement peat with $200 \mathrm{~kg} / \mathrm{m}^{3} \mathrm{GP}$ at 14 days of curing (Figure $7 \mathrm{~g}$ ).

The variation of uniaxial compression strength of stabilized peat specimens mixed with different dosage of natural fillers, at three curing times, is shown in Figure 8. In this Figure, the red line indicates the UCS of cement peat (C), while other graphs demonstrate variations of UCS of cement peat mixed with different natural fillers from dosages of 50 to $200 \mathrm{~kg} / \mathrm{m}^{3}$ by mass of wet peat at the natural moisture content of $495 \%$. As can be seen in Figure $8 \mathrm{a}$, the use of SW in dosages of 75 to $122 \mathrm{~kg} / \mathrm{m}^{3}$ at 14 days of curing time increases the UCS of cement peat from 115.2 to $125.4 \mathrm{kPa}$, while UCS of cement peat declines at dosages of 125 to $150 \mathrm{~kg} / \mathrm{m}^{3}$ from 125.4 to $111.8 \mathrm{kPa}$. It was established that if more $\mathrm{SW}$ is added in the dosage range from 150 to $200 \mathrm{~kg} / \mathrm{m}^{3}$ the UCS of cement peat declines from 111.8 to $65 \mathrm{kPa}$ (Figure $8 \mathrm{a}$ ). The same trend is shown in Figure $8 b$ for the curing time of 28 days. When the filler dosages vary between about 100 to $135 \mathrm{~kg} / \mathrm{m}^{3}$ the UCS of cement peat increases from 163.7 to $178 \mathrm{kPa}$ by using SW, whereas the UCS of cement peat declines considerably when filler dosages vary between 135 and $200 \mathrm{~kg} / \mathrm{m}^{3}$. As can be seen at 28 days of curing time, a reduction of UCS of cement peat can clearly be observed when the cement peat is mixed with GP and C-SP, while it is interesting to note that by adding $130 \mathrm{~kg} / \mathrm{m}^{3} \mathrm{~F}-\mathrm{SP}$, the UCS of cement peat increases from 163.7 to $167 \mathrm{kPa}$. This is an indication that the fine sand is more effective than the coarse one. Finally, it was established based on UCS tests at 90 days of curing that the wide range of 50 

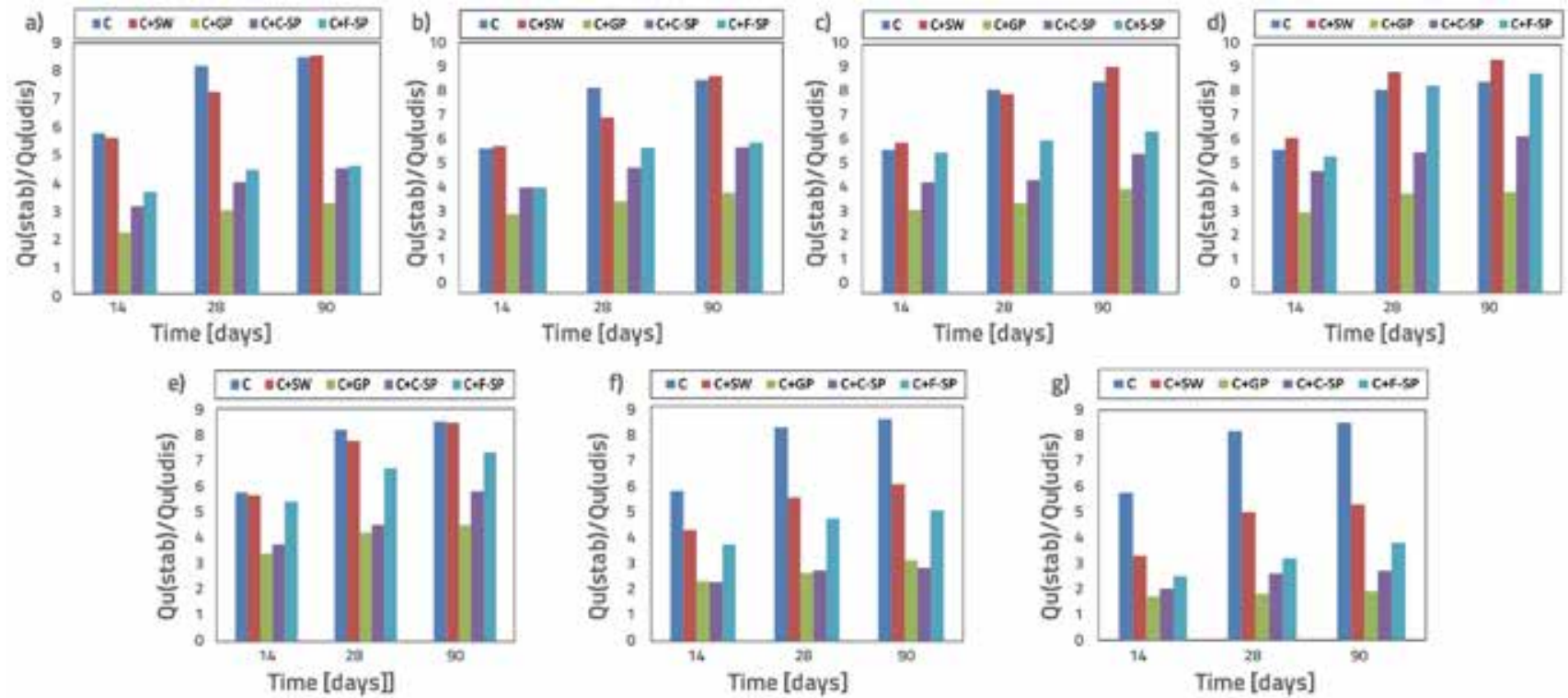

Figure 7. Comparisons of uniaxial compression strength ratios of cement peat mixed with different dosages of fillers at 14,28 and 90 days: a) 50 ; b) 75 ; c) 100 ; d) 125 ; e) 150 ; f) 175 ; g) 200 (in $\mathrm{kg} / \mathrm{m}^{3}$ )
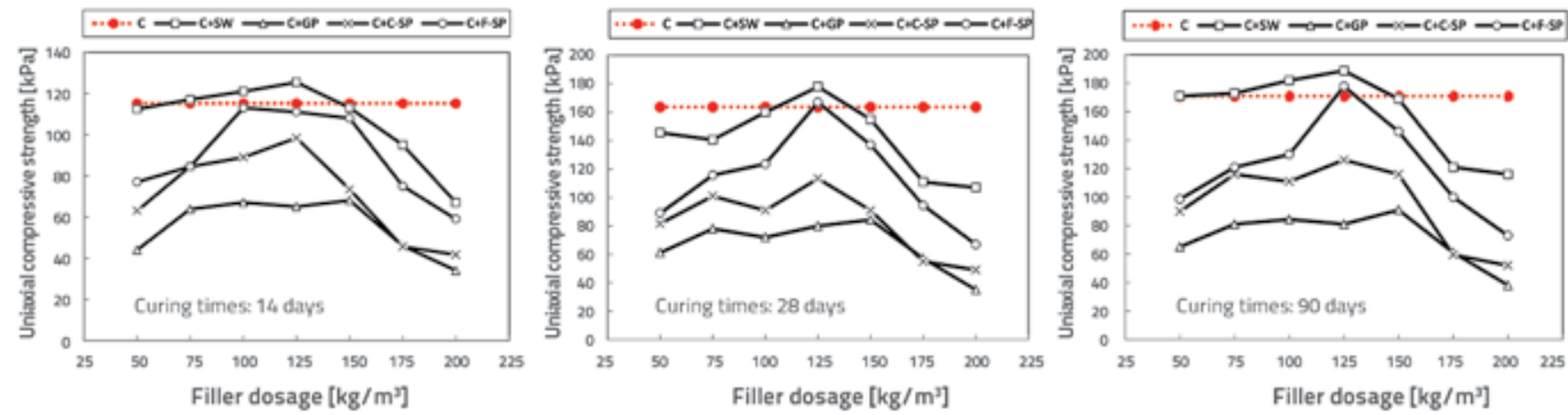

Figure 8. Unconfined compression strength of cement peat mixed with different dosages of natural fillers at different curing times

to $150 \mathrm{~kg} / \mathrm{m}^{3}$ of $\mathrm{SW}$ is effective for cement peat. The UCS increases from 170.93 to $188.8 \mathrm{kPa}$ at the dosages ranging from 50 to $120 \mathrm{~kg} / \mathrm{m}^{3}$. The trend is exactly the same as the one at 14 days curing time when SW dosages range from 120 to $200 \mathrm{~kg} / \mathrm{m}^{3}$. The same occurs at the 28 days curing time: the UCS of cement peat increases from 170.93 to $177.8 \mathrm{kPa}$ when approximately $130 \mathrm{~kg} / \mathrm{m}^{3}$ of $\mathrm{F}-\mathrm{SP}$ is added, while it should be noted that in all specimens the shear strength of cement peat decreases when GP and C-SP are used.

\section{Conclusions}

Based on the uniaxial compressive strength testing conducted on 98 cement peat specimens mixed with different dosages of natural fillers, it was observed that:
- Cement peat specimens with $300 \mathrm{~kg} / \mathrm{m}^{3}$ of cement yield the uniaxial compression strength values of $112.5,163.7$ and $170.93 \mathrm{kPa}$ at 14,28 and 90 days, respectively, which increases the uniaxial compressive strength of undisturbed peat up to $850 \%$.

- The compressive strength of cement peat decreases significantly when mixed with different dosages of poorly graded gravel, coarse poorly graded sand, and fine poorly graded sand.

- The addition of well graded sand by dosage of about $125 \mathrm{~kg} / \mathrm{m}^{3}$ of weight of wet peat, which represents the optimum filler content, increases the compressive strength of cement peat to maximum values of $125.4,178$ and 188.8 $\mathrm{kPa}$, at 14,28 and 90 days of curing time, respectively. 
Consequently, in order to increase the bearing capacity of cement fibrous peat, it is recommended to add well graded sand by dosage of about $125 \mathrm{~kg} / \mathrm{m}^{3}$ of weight of wet peat. This quantity should nevertheless be tested in field conditions.

\section{REFERENCES}

[1] Haut, B.B.K.: Some mechanical properties of tropical peat and Organic soil.In 2nd World Engineering Congress, Sarawak 22-25, 2002, 82-87

[2] Von Post, L.: Geological survey of Sweden peat inventory and some of its hitherto missing data, Tidskr, 1922, 1, 1-27.

[3] Hartlen, J., Wolsk, J.: Embankments on Organic Soils. Elsevier, USA, ISBN: 10:0-444-88273-1, 1996.

[4] Bell, F.G.: Engineering properties of soil and rocks. Malden, MA, Blackwell Sci., 2002, 202-221

[5] EUROSOILSTAB. Development of design and construction methods to stabilize soft organic soils: Design guide soft soil stabilization. CT97-0351. Industrial \& Materials Technologies Program (Brite-EuRam III), European Commission, 2002.

[6] Axelsson, K., Joansson, S., Andersson, R.: Stabilization of organic soil by cement- and puzzolanic reactions-feasibility study. Linköping, Sweden, Swedish Deep Stabilization Research Center, 2000.

[7] Kazemian, S., Prasad, A., Haut, B.B.K., Bolouri Bazaz, J., Mohammed, T.A., Abdul Aziz, F.N.: Effect of aggressive pH media on peat treated by cement and sodium silicate grout, Journal. Cent. South Univ. Technol. 2011, 18, 840-847

[8] Kazemian, S., Huat, B.B.K., Prasad, A., Barghchi, M.: Study of peat media on stabilization of peat by traditional binders. International Journal of Physical Sciences, 2011, 6 (3), 476-481.

[9] Kogure, K., Yamaguchi, H., Shogari, T.: Physical and pore properties of fibrous peat deposit proceeding of the $11^{\text {th }}$ Southeast Asian, geotechnical conferences, Singapore, 2003

[10] Munro, R.: Dealing with bearing capacity problems on low volume roads constructed on peat, 2003.

[11] Mersi, G., Ajlouni, M.: Engineering properties of fibrous peat .Journal of Geotechnical and Geoenvironmental Engineering. 2007, Vol. 133, No. 7

\section{Acknowledgment}

The authors would like to acknowledge the financial support given by the School of Graduate Studies (SPS) - Universiti Technologi Malaysia. This support is gratefully appreciated.
[12] Wong, S., Roslan, H., Faisal, A.: Unconfined compressive strength characteristics of stabilized peat, Scientific Research and Essays Vol. 6(9), 2011, 1915-1921

[13] Islam, M.D., Hashim, R.: Stabilization of peat soil by soil-column technique and settlement of group columns, International Journal of the Physical Sciences Vol. 5(9), 2010, 1411-1418.

[14] Yang, S.D., Yagihashi, J.N., Yoshizava, S.S.: Dry jet mixing for stabilization of very soft soils and organic soils. Geotechnical Special Publication,1998, 96-110.

[15] Hebib, S., Farrel, E.R.: Some experiences on the stabilization of Irish peats. Can Geotech J, 2003, 40 (1), 107-120.

[16] Broms, B.: Lime and lime/cement columns.Proceedings of $4^{\text {th }}$ International Conference on Ground Improvement Geosystems, Helsinki,2003, 43-93.

[17] Wong, S., Roslan, H., Faisal, A.: Strength and permeability of peat soil, Journal of Applied Sciences, Vol. 8, Issue 15, 2008:1-5.

[18] Chen, H., Wang, Q.: The behavior of organic matter in the process of soft soil stabilization using cement. Bull Eng Geol Environ, 2006, 65, 445-448.

[19] Aagnostopoulos, A., Chatzianglou, M.: Compressive strength of cement stabilized soil. Electronic journal of geotechnical engineering.2008:13, 1-10.

[20] Dehghanbanadaki, A., Kamarudin, A., Nazri, A.: Initial settlement of mat foundation on group of cement columns in peat - numerical analysis. Electronic journal of geotechnical engineering. Vol 17/0, 2012, 2243-2253.

[21] British Standard Institution. Methods of test for soils for civil engineering purposes. London, UK, BS 1377- 1990: Part 2, 3, 6 and 7, 1990.

[22] Head, K.H., Epps, R.J.: Manual of soil laboratory testing. Vol. 2, 2011, 324-340

[23] American Society for Testing. Materials Annual: Annual book of ASTM standards. Philadelphia, PA, USA, 1992, 04.08. 